\title{
Real-Time PCR Assay for the Identification of the Brown Marmorated Stink Bug (Halyomorpha halys)
}

\author{
Manpreet K. Dhami ${ }^{1,2 *}$, Melissa Dsouza ${ }^{3}$, David W. Waite ${ }^{1}$, Diane Anderson ${ }^{1}$ and \\ Dongmei $\mathrm{Li}^{1}$
}

${ }^{1}$ Plant Health and Environment Laboratory, Ministry for Primary Industries, Auckland, New Zealand, ${ }^{2}$ Department of Biology, Stanford University, Stanford, CA, USA, ${ }^{3}$ Department of Ecology and Evolution, University of Chicago, Chicago, IL, USA

\section{OPEN ACCESS}

Edited by:

Arun Bhardwaj,

University of South Alabama Mitchell

Cancer Institute, USA

Reviewed by:

Prashant Singh,

University of Georgia, USA

Shivalika Saxena,

Columbia University in the City of New

York, USA

Iffat Parveen,

University of Mississippi, USA

*Correspondence:

Manpreet K. Dhami manpreetkdhami@gmail.com

Specialty section:

This article was submitted to Molecular Diagnostics,

a section of the journal

Frontiers in Molecular Biosciences

Received: 04 November 2015 Accepted: 04 February 2016

Published: 26 February 2016

Citation:

Dhami MK, Dsouza M, Waite DW Anderson D and Li D (2016) Real-Time PCR Assay for the Identification of the Brown Marmorated Stink Bug (Halyomorpha halys). Front. Mol. Biosci. 3:5 doi: 10.3389/fmolb.2016.00005
The brown marmorated stink bug, Halyomorpha halys (Hemiptera: Pentatomidae), is a gregarious crop pest that has rapidly spread across the world in the last two decades. It is an excellent hitchhiker species, especially as an over-wintering adult. During this period it is often associated with non-biological commodities such as shipping containers and machinery that travel long distances. Inadequate identification keys and similarity to common species has assisted its spread across Europe, while accurate identification from immature stages or eggs is not possible. We developed a real-time TaqMan PCR assay for the accurate and sensitive detection of the brown marmorated stink bug from all life stages. The assay performance against required diagnostic criterion and within a quarantine framework are described.

Keywords: qPCR, invasive species, diagnostic test, Pentatomidae, biosecurity

\section{INTRODUCTION}

Effective management of a pest relies heavily on is its rapid and accurate identification. Such techniques are often not available for newly emerging pests, for example, the brown marmorated stink bug (BMSB), Halyomorpha halys (Hemiptera: Pentatomidae). A plant pest affecting ornamentals, crops, weeds and even forest trees, the BMSB poses an economic threat to a wide variety of fruit crops including apples, pears, persimmon and peaches across China, Japan, Korea, and the USA (Funayama, 2004; Yu and Zhang, 2007; Nielsen and Hamilton, 2009; Son et al., 2009). Brown marmorated stink bug is an insect vector of the phytoplasma disease of Paulownia tomentosa (empress tree or foxglove tree) in Asia and is a suspected vector of other phytoplasmas (Jones and Lambdin, 2009). Additionally, it is a public nuisance as adult stink bugs aggregate in large numbers on the outside of buildings in late autumn, eventually entering them to overwinter (Hamilton, 2009), and discharging an unpleasant and long lasting odor on disturbance.

The BMSB is native to China, Japan, Korea and Taiwan but has rapidly spread around the world. It has recently invaded North America causing significant economic losses in the fruit industry as well as exerting pressure to soybean crops within 8 years of detection (Nielsen and Hamilton, 2009; Nielsen et al., 2011). It is now found across eastern and western United States, and Alberta, British Columbia, Ontario and Quebec in Canada (Jones and Lambdin, 2009). A similar spread of BMSB has also been reported across mainland Europe, with the first interception in Switzerland in 2004 (Wermelinger et al., 2008), and subsequent records from Germany (2011) (Heckmann, 2012), 
France (2012) (Callot and Brua, 2013), Hungary (2013) (Vétek et al., 2014), Greece (2011) (Milonas and Partsinevelos, 2014) and Italy (2013) (Maistrello et al., 2014). Between 2005 and October 2015, it has been intercepted 83 times at the New Zealand (Harris, 2010; IDC PHEL, 2013). It could likely enter New Zealand as a hitchhiker on non-biological items, as well as biological items such as fresh produce, cut flowers or nursery stock. New Zealand falls under high risk of establishment for this species based on its current global distribution. Recent modeling by Zhu et al. (2012) identifies New Zealand as having high climate suitability for the establishment of BMSB. In part due to the high interception rate, as well as its ability to spread, it is important to develop rapid and sensitive identification techniques that are independent of the target organism's life stage.

The BMSB belongs to the subfamily Pentatominae that comprises 54 described genera and hundreds of species. The genus Halyomorpha has 16 described species from Sub-Saharan Africa alone (Robertson, 2009). Little is known of this genus from the rest of the world. The only two species for which cytochrome c oxidase sequences are available on online databases such as GenBank and BOLD are Halyomorpha halys and H. picus. A total of 23 haplotypes based on the COI sequences of BMSB have been described, suggesting high variability within the species (Xu et al., 2013). Similarly, 19 haplotypes based on the $12 \mathrm{~S}$ ribosomal RNA gene sequence and 18 haplotypes based on the COII gene sequence were found in the invaded regions of Asia (Xu et al., 2013). Of these only two 12 S haplotypes and one COII haplotype were found in the invaded regions of USA (Xu et al., 2013). It is possible that a more conserved region such as the $28 \mathrm{~S}$ or COI would be more suitable for the developmenmt of a qPCR assay. However, only few sequences of these genes from closely related organisms were available in the databases.

This study provides a species-specific and sensitive TaqMan real-time PCR assay for the identification of BMSB. The target gene for the development of this assay is cytochrome oxidase I (COI), since it is well described for most insect species including Pentatomidae. The developed assay as well as performance criteria such as analytical and diagnostic specificity, sensitivity, repeatability, reproducibility and blind panel testing, are reported here.

\section{MATERIALS AND METHODS}

\section{Sample Collection and Identification}

Brown marmorated stink bug samples intercepted at the New Zealand borders largely constituted the tested samples. These intercepted samples originated from a wide range of locations, including China, Japan and USA. Few Pentatomidae are present in New Zealand, and none from the genus Halyomorpha. Fourteen species of Pentatomidae and close relatives from New Zealand were obtained from the Plant Health and Environment Laboratory (PHEL, Auckland New Zealand) collections, as well as from Canada, Japan, USA and China. All samples were identified morphologically by entomologists at PHEL, and identifications were confirmed by sequencing their barcode region, as discussed below. Voucher specimens for each organism are held in the PHEL ethanol and voucher collections and are available upon request. All organisms imported into New Zealand were in accordance to the Import Health Standard, Section 22 of the Biosecurity Act 1993. Ethics approval was not required as insects are not classified as animals for the purposes of the Animal Welfare Act, 1999, New Zealand Legislation.

\section{DNA Extraction, PCR Amplification and Sequencing}

Total gDNA was extracted using DNeasy Blood and Tissue kit (Qiagen, CA, USA). A single leg was physically disrupted and finely chopped with sterile scissors. DNA quantification was conducted using the MultiSkan GO DNA quantification system with a $\mu$ Drop* plate (Thermo Fisher Scientific, MA, USA).

All the samples used in the assay development were identified via conventional PCR amplification and sequencing of the COI gene region, using the COI primer pair, LCO1490 and HCO2198 (Folmer et al., 1994). Each $20 \mu \mathrm{L}$ reaction consisted of Red N'Amp master mix (Sigma-Aldrich Co., MO, USA), $250 \mathrm{nM}$ of each primer, $0.04 \mu \mathrm{g} / \mu \mathrm{L}$ Bovine Serum Albumin (BSA) (SigmaAldrich Co.), 2-5 ng of DNA template and PCR-grade water. PCR cycling with a $2 \mathrm{~min}$ initial denaturation at $94^{\circ} \mathrm{C}$, was followed by 30 cycles of $15 \mathrm{~s}$ at $94^{\circ} \mathrm{C}, 30 \mathrm{~s}$ at $52^{\circ} \mathrm{C}$ and $45 \mathrm{~s}$ at $72^{\circ} \mathrm{C}$, followed by a final extension step of $7 \mathrm{~min}$ at $72^{\circ} \mathrm{C}$. The approximately $700 \mathrm{bp}$ amplicons were visualized via gel electrophoreses as described in Dhami and Kumarasinghe (2014). PCR products were sequenced bi-directionally using the amplification primers, by EcoGene (Auckland, New Zealand). All sequences were edited using Geneious version 7.1.5 (Kearse et al., 2012). Sequences were compared to the NCBI GenBank nucleotide or BOLD (Ratnasingham and Hebert, 2007) databases using BLAST (Altschul et al., 1990) to confirm morphological identification. These sequences were used to guide the development of the assay.

\section{Real-Time PCR Assay Design and Optimization}

COI gene sequences of Pentatomidae, especially of the closely related Pentatominae, were obtained from samples described above, and were also downloaded from GenBank and BOLD sequence databases (Table S1). A unique region of the BMSB sequence was selected from the alignment and Beacon Designer 8.01 (Premier Biosoft, Palo Alto, CA, USA) was used to design the assay. Multiple primer and probe options were generated, and the best assay was determined as the primer and probe combination that maximized mismatches with closely related sequences.

A real-time PCR protocol was developed using BMSB positive control samples as well as several non-target species samples as negative controls. The designed primers and probes were tested on a CFX96 Touch Real-time platform (BioRad, Hercules, CA, USA). Assay was optimized using gradient PCR for annealing temperature $\left(60-65^{\circ} \mathrm{C}\right)$, primer concentration $(200$ and $400 \mathrm{nM}$ ), and probe concentration (200 and $400 \mathrm{nM}$ ) using the SsoAdvanced Probes Mix (BioRad, Hercules, CA). For each reaction, 96-well clear bottom plates were used and all samples, standards and controls were run in duplicate wells. Fluorescence data was acquired to the FAM channel at the end of each cycle. 
The amplification curves were visualized using the CFX Manager Software v. 3.0 (BioRad).

\section{Analytical and Diagnostic Specificity of the Assay}

We included a total of 63 voucher specimens in this assay of which 13 were target and the remaining non-target species. Percentage of samples of known identity of the target that return a positive result contribute to the analytical specificity and nontarget samples that return a negative result contribute to the diagnostic specificity of the assay. All the samples used for assay validation were identified prior to testing by conventional PCR and sequencing.

\section{Analytical Sensitivity, Amplification Efficiency, Repeatability and Reproducibility of the Assay}

As described in Dhami et al. (2015), a 714 bp template COI gene region was used to prepare plasmid standards and diluted to a series of known copy number. Amplicon cloning was performed using the TOPO TA vector Cloning kit (Invitrogen, Carlsbad, CA, USA) as per the manufacturer's instructions, for two biological samples PQ20 and PQ23. For each sample, two clones, containing the correct insert were selected for preparing standards.

Plasmid DNA was extracted, quantified and digested to linearize it, as described previously (Dhami and Kumarasinghe, 2014; Dhami et al., 2015). Copy number was calculated as described previously (Dhami et al., 2015).

A dilution series of $10^{9}-10$ copies of linearized plasmid/reaction, run in triplicate, was used to determine the analytical sensitivity of the developed assay. Amplification curves were fitted using linear regression in the $\mathrm{R}$ environment (R Core Team, 2013). The qpcR package was used to calculate the efficiency of the reaction using the formula, $E=(10-1 /$ slope $)$ (Ritz and Spiess, 2008), following conversion to percentage efficiency, and the fit of the slope was recorded as $r^{2}$. Standard curve data were used to calculate linear dynamic range and limit of detection (Bustin et al., 2009).

Intra-run variation or repeatability and inter-run variation or reproducibility were calculated by $C q$ mean standard deviation and percent coefficient of variation $(\% \mathrm{CV})$ for this nonquantitative assay. We tested five samples in triplicate, in two separate runs and calculated the $\% \mathrm{CV}$ for each sample, to estimate repeatability. We compared the data from the two runs to estimate reproducibility.

\section{Blind Panel Validation of the Assay}

A total of 24 insect samples were used for blind panel testing. These samples were obtained from 12 different Pentatomidae species, representing various life stages and body parts, largely interceptions at the New Zealand borders. DNA extraction and quantification was performed as previously described. Samples were tested in duplicate and positive controls and no template controls were included. All samples were tested simultaneously with an internal positive control using a commercial $18 \mathrm{~S}$ realtime
PCR kit (Applied Biosystems, CA, USA). These experiments were essentially a simulation of the New Zealand quarantine framework, in which the developed assay was applied.

\section{RESULTS}

\section{BMSB Assay: Identification via Taqman Real-Time PCR}

Primer pair, HhalldF $\left(5^{\prime}-\mathrm{GAG}\right.$ GAT TCG GTA ATT GAT TA-3') and HhalldR2 (5'-GTG AGA TAT TAC TTG ATA AGG-3'), amplify a 186 bp of the target sequence. Probe Hhal4P (5'-CTG ATA TAG CCT TCC CAC GAT TAA AT$3^{\prime}$ ), was selected after rigorous in silico testing for binding against the sequence alignments using Geneious. The final probe was synthesized with 5'FAM and 3'BHQ-1 modifications by Biosearch Technologies (CA, USA). Based on gradient PCR results, final cycling conditions were selected as follows: $95^{\circ} \mathrm{C}$ for $2 \mathrm{~min}$, followed by 40 cycles of denaturing $\left(95^{\circ} \mathrm{C}\right.$ for $\left.15 \mathrm{~s}\right)$ and annealing/extension $\left(62^{\circ} \mathrm{C}\right.$ for $\left.45 \mathrm{~s}\right)$, followed by a plate read step. Reactions contained $400 \mathrm{nM}$ of each primer with $200 \mathrm{nM}$ of probe. Approximately, 10-30 ng/uL of template DNA was used for the PCR assay. The assay cut-off was set at 35 cycles to reduce possible non-specific binding.

\section{Analytical and Diagnostic Specificity of the Assay}

Of the 63 samples tested, 13 were target and the remaining nontarget species. All the target BMSB samples amplified within the $C q$ cut-off of 35 cycles (Table 1). None of the non-target samples amplified within this range. Therefore, the analytical as well as the diagnostic specificity of the assay were $100 \%$.

\section{Analytical Sensitivity and Performance of the Assay}

The PCR efficiency was calculated at $97.0 \%$, which is within the 95-105\% range generally accepted for an efficient PCR reaction (Figure 1). The linear dynamic range of the assay was established as $10^{9}-100$ copies of template DNA. The correlation coefficient, $r^{2}$, of the calibration curve was 0.99 . The $98 \%$ confidence limits of the linear dynamic range are plotted in Figure 1. Very low variation $(\% \mathrm{CV})$ was observed for each of the samples tested within individual runs (repeatability) and between different runs (reproducibility) indicating high assay reproducibility (Table 2 ).

\section{Blind Panel Validation of the Assay}

Ten out of the 24 samples of unknown identity were accurately identified as BMSB (Table 3). No false-positive and false-negative results were obtained. All test results matched to the original sample idenitites independently.

\section{DISCUSSION}

Real-time PCR-based technique have revolutionized pathogen identification throughout the world. Fungi, bacteria and viruses provide excellent examples of plant pathogens that are regularly identified using real-time PCR (Mackay et al., 2002; Bilodeau et al., 2007; Osman et al., 2007; Monti et al., 2013). However, 
TABLE 1 | Samples used for specificity testing of the BMSB assay.

\begin{tabular}{|c|c|c|c|c|c|}
\hline Species & Origin & $\begin{array}{l}\text { Collection } \\
\text { date }\end{array}$ & $\begin{array}{l}\text { Number } \\
\text { of } \\
\text { samples }\end{array}$ & $\begin{array}{c}\text { Samples } \\
\text { tested } \\
\text { positive }\end{array}$ & $\begin{array}{l}\text { Median } \\
\qquad \boldsymbol{C q}\end{array}$ \\
\hline $\begin{array}{l}\text { Acrosternum } \\
\text { hilare }\end{array}$ & Canada & 2013 & 5 & 0 & - \\
\hline $\begin{array}{l}\text { Banasa } \\
\text { dimidiata }\end{array}$ & Canada & 2013 & 5 & 0 & - \\
\hline $\begin{array}{l}\text { Brochymena } \\
\text { quadripustulata }\end{array}$ & Canada & 2013 & 5 & 0 & - \\
\hline $\begin{array}{l}\text { Chlorochroa } \\
\text { persimilis }\end{array}$ & Canada & 2013 & 5 & 0 & - \\
\hline $\begin{array}{l}\text { Dolycoris } \\
\text { baccarum }\end{array}$ & Canada & 2013 & 3 & 0 & - \\
\hline Erthesina fullo & Japan & $\begin{array}{l}2012 \\
2013\end{array}$ & 2 & 0 & - \\
\hline $\begin{array}{l}\text { Euchistus } \\
\text { tristigmus }\end{array}$ & Canada & 2013 & 5 & 0 & - \\
\hline Glaucias amyoti & $\begin{array}{l}\text { New } \\
\text { Zealand }\end{array}$ & 2015 & 1 & 0 & - \\
\hline $\begin{array}{l}\text { Halyomorpha } \\
\text { halys }\end{array}$ & $\begin{array}{l}\text { USA, } \\
\text { China, } \\
\text { Japan }\end{array}$ & $\begin{array}{l}2012 \\
2013\end{array}$ & 13 & 13 & 19.35 \\
\hline Nezara sp. & Japan & 2013 & 1 & 0 & - \\
\hline Nezara viridula & Canada & 2013 & 5 & 0 & - \\
\hline $\begin{array}{l}\text { Parabrochymena } \\
\text { arborea }\end{array}$ & Canada & 2013 & 5 & 0 & - \\
\hline $\begin{array}{l}\text { Podisus } \\
\text { maculiventris }\end{array}$ & Canada & 2013 & 5 & 0 & - \\
\hline $\begin{array}{l}\text { Rhaphigaster } \\
\text { nebulosa }\end{array}$ & Canada & 2013 & 3 & 0 & - \\
\hline
\end{tabular}

species-specific real-time PCR assays are only available for a fraction of insects, which form a large and diverse group of plant pests. These assays are available for difficult to identify and economically significant pests such as Thrips palmi (Walsh et al., 2005) and Bactrocera latifrons (Yu et al., 2004). Each species causes severe agricultural damage and are often intercepted as immatures, thereby hindering morphological identification. Similarly, BMSB, which is an emerging pest of high economic and public significance, is also difficult to identify as an egg or in its immature stages. In this study, we have developed a novel real-time PCR assay for the detection and identification of BMSB. Using real-time PCR eliminates post-PCR processing, reducing identification time by several hours. TaqMan probes provide high specificity (Mao et al., 2007) and can be performed at any laboratory.

During the development stage, thorough in silico testing was followed by experimental analysis during the specificity testing stage. We analyzed a total of 12 Pentatomidae species during the specificity testing stage (Table 1). In New Zealand, this assay is routinely used for the identification of BMSB, especially from eggs and nymphs. In other countries, we would recommend further specificity testing prior to deployment. One closely related species, with a COI sequence similar to that of BMSB, is Halyomorpha picus. Although not tested specifically here, this insect contains multiple mismatches in both primers (F: 2-4 and R: $2-3$ sites) and probe (P: 1-5 sites) and is unlikely to

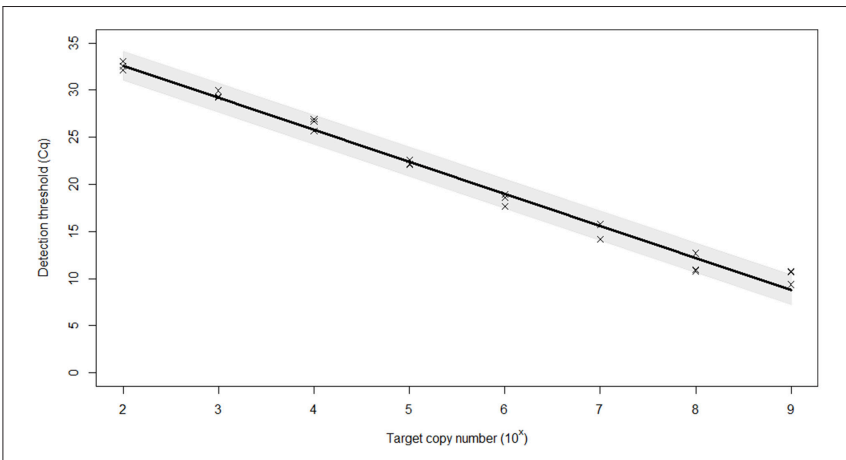

FIGURE 1 | Efficiency of the real-time PCR assay for the identification of BMSB. Plasmid dilution series were used to create calibration curves for efficiency calculations. The standard curve built from Cq (threshold cycle) values against the log copy number (range $=10^{9}-10^{2}$ copies). The $98 \%$ confidence interval of the slope is shaded. Based on curve statistics, the assay efficiency is $97.0 \%$ and the $r^{2}$ (fit) $=0.99$.

TABLE 2 | Repeatability and reproducibility of BMSB assay, measured as percentage coefficient of variation (\%CV).

\begin{tabular}{lccl}
\hline Sample & $\begin{array}{c}\text { Repeatability } \\
\text { (assay 1) }\end{array}$ & $\begin{array}{c}\text { Repeatability } \\
\text { (assay 2) }\end{array}$ & Reproducibility \\
\hline Sample 7 & 1.81 & 0.49 & 4.26 \\
Sample 8 & 1.13 & 6.73 & 5.31 \\
Sample 12 & 3.91 & 2.99 & 3.49 \\
Sample 13 & 0.93 & 1.22 & 3.05 \\
Sample 20 & 0.69 & 2.05 & 3.22 \\
\hline
\end{tabular}

Repeatability is defined as the intra-run variation of a sample and reproducibility as the inter-run variation of a sample. Sample identifiers reflect sample number in blind panel testing (Table 3).

successfully anneal to these molecules during the PCR process (Supplemental Figure S1).

One hundred percent diagnostic and analytical specificity, from samples derived from legs of adults, was reported for this assay. Such accuracy and reliability is optimal for diagnostics. The high efficiency and sensitivity, and the ability to identify as low as 100 copies of the target DNA, which is 5 orders of magnitude less than that obtained from a typical extraction further accredits the consistency of the assay results (data not shown). Two well replicated calibration curves validated the limit of detection. Additionally, the extremely low intra-assay and inter-assay variance permits the applicability of the assay across different laboratories a feasible option.

The application of a diagnostic assay within the New Zealand quarantine framework is characterized by three main tenets: high specificity, high sensitivity and swift results. This assay fulfills each of these criteria. The final validation using a blind panel provides further confidence that this assay can be reliably used in a routine diagnostic framework in New Zealand and overseas. It is important to note that border-intercepted organisms were included in the panel to simulate a realistic situation, and border intercepted BMSB samples were also included.

In conclusion, the novel TaqMan qPCR assay developed here is ideally suited for research and diagnostic agencies, in the facilitation of trade, as well as an aid to the border 
TABLE 3 | Blind panel testing of BMSB assay.

\begin{tabular}{|c|c|c|c|c|c|c|}
\hline Sample & Life stage & Morphological ID & Sample origin & $C q$ (18S control) & Cq (BMSB assay) & Diagnostic result \\
\hline 1 & Nymph & Monteithiella humeralis & $N Z$ & 29.3 & - & $x$ \\
\hline 2 & Adult & Cuspicona simplex & $\mathrm{NZ}$ & 19.9 & - & $x$ \\
\hline 3 & Adult & Halyomorpha halys & USA & 17.4 & 19.4 & $\checkmark$ \\
\hline 4 & Nymph & Nezara viridula & $N Z$ & 28.1 & - & $x$ \\
\hline 5 & Adult & Halyomorpha halys & USA & 15.2 & 20.1 & $\checkmark$ \\
\hline 6 & Adult & Erthesina fullo & Japan & 24.5 & - & $x$ \\
\hline 7 & Adult & Halyomorpha halys & USA & 25.0 & 23.5 & $\checkmark$ \\
\hline 8 & Adult & Halyomorpha halys & USA & 19.9 & 20.5 & $\checkmark$ \\
\hline 9 & Nymph & Nezara viridula & $N Z$ & 30.1 & - & $x$ \\
\hline 10 & Adult & Halyomorpha halys & USA & 19.6 & 22.6 & $\checkmark$ \\
\hline 11 & Adult & Erthesina fullo & Korea or China & 18.3 & - & $x$ \\
\hline 12 & Adult & Halyomorpha halys & USA & 18.3 & 23.1 & $\checkmark$ \\
\hline 13 & Adult & Halyomorpha halys & - & 17.2 & 19.3 & $\checkmark$ \\
\hline 14 & Adult & Halyomorpha halys & Japan & 31.2 & 29.2 & $\checkmark$ \\
\hline 15 & Egg & Murgantia histrionica & USA & 25.5 & - & $x$ \\
\hline 16 & Adult & Erthesina fullo & China & 13.0 & - & $x$ \\
\hline 17 & 3rd instar & Bagrada hilaris & USA & 18.9 & - & $x$ \\
\hline 18 & Adult & Eysarcoris sp. & South Korea & 21.2 & - & $x$ \\
\hline 19 & Adult & Dictyctus caenoeus & AK & 28.9 & - & $x$ \\
\hline 20 & Adult & Halyomorpha halys & USA & 20.8 & 18.5 & $\checkmark$ \\
\hline 21 & Adult & Halyomorpha halys & USA & 17.9 & 21.6 & $\checkmark$ \\
\hline 22 & Adult & Nezara viridula & Canada & 17.0 & - & $x$ \\
\hline 23 & Adult & Nezara viridula & Canada & 16.8 & - & $x$ \\
\hline 24 & Adult & Nezara viridula & Canada & 16.9 & - & $x$ \\
\hline
\end{tabular}

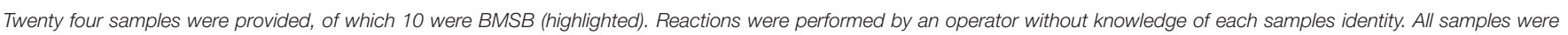
amplified using the TaqMan Ribosomal 18S RNA control assay. The Cq value for each reaction was the only criteria for the identification as BMSB.

security agencies worldwide, to slow the further spread of this pest. As a rapid, accurate and specific alternative to morphology- or conventional PCR-based techniques, it saves precious quarantine time. With the availability of 96-well or 384well format PCR machines, which can be coupled with semiautomated extraction methods, this method is amenable to high throughput applications. Such applications are often deemed necessary during large scale surveys for delimiting infestations during an incursion. Like any other diagnostic assay, predeployment testing in locations other than New Zealand is highly recommended, to ensure that no false positives exist, although they would be highly unlikely.

\section{AUTHOR CONTRIBUTIONS}

MKD, DL designed the study. MKD, MD, DW performed the experiments. MKD, DW did the analysis. MKD, DW, DL, DA sourced the materials. MKD, DW wrote the manuscript. All authors edited and read the final version of the manuscript.

\section{ACKNOWLEDGMENTS}

The authors would like to thank Dr Suzanne Keeling and Dr Lalith Kumarasinghe for their support with this project.
We would also like to thank Dr Catia Delmiglio for technical advice and manuscript preparation and Dr Andrew Letten for comments on the manuscript. We would also like to thank Dr Tara Gariepy, Agriculture and Agri-Food Canada for collecting the samples from Canada. This work was supported by the Ministry for Primary Industries Operational Research Grant \#12-14.

\section{SUPPLEMENTARY MATERIAL}

The Supplementary Material for this article can be found online at: http://journal.frontiersin.org/article/10.3389/fmolb. 2016.00005

Supplemental Figure S1 | Neighbor-joining tree of Pentatomidae target sites. Sequences obtained represent the BMSB and other Pentatomidae sequences used in assay development and validation, as well as BMSB and $H$. picus sequences obtained from online sources. Sequences were aligned and regions corresponding to the forward primer, probe, and reverse primer binding site extracted and concatenated into a single sequence. Tree building was performed using neighbor-joining with a Jukes-Cantor distance model. Support of nodes was obtained through 10,000 bootstrap iterations.

Table S1 | Accession numbers of the sequences of the samples used in the design phase and the specificity-testing phase of the assay development. 


\section{REFERENCES}

Altschul, S. F., Gish, W., Miller, W., Myers, E. W., and Lipman, D. J. (1990). Basic local alignment search tool. J. Mol. Biol. 215, 403-410. doi: 10.1016/S00222836(05)80360-2

Bilodeau, G., Lévesque, C., De Cock, A., Duchaine, C., Brière, S., Uribe, P., et al. (2007). Molecular detection of Phytophthora ramorum by real-time polymerase chain reaction using TaqMan, SYBR Green, and molecular beacons. Phytopathology 97, 632-642. doi: 10.1094/PHYTO-97-5-0632

Bustin, S. A., Benes, V., Garson, J. A., Hellemans, J., Huggett, J., Kubista, M., et al. (2009). The MIQE guidelines: minimum information for publication of quantitative real-time PCR experiments. Clin. Chem. 55, 611-622. doi: 10.1373/clinchem.2008.112797

Callot, H., and Brua, C. (2013). Halyomorpha halys (Stål, 1855), la Punaise diabolique, nouvelle espèce pour la faune de France (Heteroptera: Pentatomidae). L'Entomologiste 69, 69-71.

Dhami, M. K., Gunawardana, D., Voice, D., and Kumarasinghe, L. (2015). A realtime PCR toolbox for accurate identification of invasive fruit fly species. J. Appl. Entomol. doi: 10.1111/jen.12286. [Epub ahead of print].

Dhami, M. K., and Kumarasinghe, L. (2014). A HRM real-time PCR assay for rapid and specific identification of the emerging pest Spotted-Wing Drosophila (Drosophila suzukii). PLoS ONE 9:e98934. doi: 10.1371/journal.pone.00 98934

Folmer, O., Black, M., Hoeh, W., Lutz, R., and Vrijenhoek, R. (1994). DNA primers for amplification of mitochondrial cytochrome $c$ oxidase subunit I from diverse metazoan invertebrates. Mol. Marine Biol. Biotechnol. 3, 294-299.

Funayama, K. (2004). Importance of apple fruits as food for the brownmarmorated stink bug, Halyomorpha halys (Stål) (Heteroptera: Pentatomidae). Appl. Entomol. Zool. 39, 617-623. doi: 10.1303/aez.2004.617

Hamilton, G. C. (2009). Brown marmorated stink bug. Am. Entomol. 55, 19-20. doi: $10.1093 / \mathrm{ae} / 55.1 .19$

Harris, A. C. (2010). Halyomorpha halys (Hemiptera: Pentatomidae) and Protaetia brevitarsis (Coleoptera: Scarabaeidae: Cetoniinae) intercepted in Dunedin. Weta $40,42-44$.

Heckmann, R. (2012). Erster nachweis von Halyomorpha halys (stål, 1855)(Heteroptera: Pentatomidae) für deutschland. Heteropteron 36, 17-18.

IDC PHEL (2013). Plant Health \& Environment Laboratory, "LIMS Database," Edn. Auckland: Ministry for Primary Industries.

Jones, J. R., and Lambdin, P. L. (2009). New county and state records for Tennessee of an exotic pest, Halyomorpha halys (Hemiptera: Pentatomidae), with potential economic and ecological implications. Florida Entomol. 92, 177-178. doi: $10.1653 / 024.092 .0132$

Kearse, M., Moir, R., Wilson, A., Stones-Havas, S., Cheung, M., Sturrock, S., et al. (2012). Geneious Basic: an integrated and extendable desktop software platform for the organization and analysis of sequence data. Bioinformatics 28 , 1647-1649. doi: 10.1093/bioinformatics/bts199

Mackay, I. M., Arden, K. E., and Nitsche, A. (2002). Real-time PCR in virology. Nucl. Acids Res. 30, 1292-1305. doi: 10.1093/nar/30.6.1292

Maistrello, L., Dioli, P., Vaccari, G., Nannini, R., Bortolotto, P., Caruso, S., et al. (2014). First records in Italy of the Asian stinkbug Halyomorpha halys, a new threat to fruit crops. ATTI Giornate Fitopatol. 1, 283-288.

Mao, F., Leung, W.-Y., and Xin, X. (2007). Characterization of EvaGreen and the implication of its physicochemical properties for $\mathrm{qPCR}$ applications. $B M C$ Biotechnol. 7:76. doi: 10.1186/1472-6750-7-76

Milonas, P., and Partsinevelos, G. (2014). First report of brown marmorated stink bug Halyomorpha halys Stål (Hemiptera: Pentatomidae) in Greece. EPPO Bull. 44, 183-186. doi: 10.1111/epp.12129

Monti, M., Martini, M., and Tedeschi, R. (2013). EvaGreen Real-time PCR protocol for specific 'Candidatus Phytoplasma mali' detection and quantification in insects. Mol. Cell. Probes 27, 129-136. doi: 10.1016/j.mcp.2013.02.001
Nielsen, A. L., and Hamilton, G. C. (2009). Seasonal occurrence and impact of Halyomorpha halys (Hemiptera: Pentatomidae) in tree fruit. J. Econ. Entomol. 102, 1133-1140. doi: 10.1603/029.102.0335

Nielsen, A. L., Hamilton, G. C., and Shearer, P. W. (2011). Seasonal phenology and monitoring of the non-native Halyomorpha halys (Hemiptera: Pentatomidae) in soybean. Environ. Entomol. 40, 231-238. doi: 10.1603/EN10187

Osman, F., Leutenegger, C., Golino, D., and Rowhani, A. (2007). Realtime RT-PCR (TaqMan ${ }^{\circledR}$ ) assays for the detection of Grapevine Leafroll associated viruses 1-5 and 9. J. Virol. Methods 141, 22-29. doi: 10.1016/j.jviromet.2006.11.035

Ratnasingham, S., and Hebert, P. D. N. (2007). BOLD: the barcode of life data system. Mol. Ecol. Notes 7, 355-364. doi: 10.1111/j.1471-8286.2007.01678.x. Available online at: http://www.barcodinglife.org

R Core Team (2013). R: A Language and Environment for Statistical Computing. Vienna: R Foundation for Statistical Computing.

Ritz, C., and Spiess, A.-N. (2008). qpcR: an R package for sigmoidal model selection in quantitative real-time polymerase chain reaction analysis. Bioinformatics 24 , 1549-1551. doi: 10.1093/bioinformatics/btn227

Robertson, I. A. D. (ed.). (2009). The Pentatomoidea (Hemiptera: Heteroptera) of Sub-Saharan Africa. Leiden: Natural Museum of Natural History, Naturalis.

Son, J. K., Yun, J. E., and Park, C. G. (2009). Insect pest problems of sweet persimmon in Korea. Acta Horicult. 933, 325-330. doi: 10.17660/ActaHortic.2009.833.52

Vétek, G., Papp, V., Haltrich, A., and Redei, D. (2014). First record of the brown marmorated stink bug, Halyomorpha halys (Hemiptera: Heteroptera: Pentatomidae), in Hungary, with description of the genitalia of both sexes. Zootaxa 3780, 194-200. doi: 10.11646/zootaxa.3780.1.8

Walsh, K., Boonham, N., Barker, I., and Collins, D. W. (2005). Development of a sequence-specific real-time PCR to the melon thrips Thrips palmi (Thysan., Thripidae). J. Appl. Entomol. 129, 272-279. doi: 10.1111/j.14390418.2005.00960.x

Wermelinger, B., Wyniger, D., and Forster, B. (2008). First records of an invasive bug in Europe: Halyomorpha halys Stal (Heteroptera: Pentatomidae), a new pest on woody ornamentals and fruit trees? Mitteilungen Schweizer. Entomol. Gesellsc. 81, 1-8.

Xu, J., Fonseca, D. M., Hamilton, G. C., Hoelmer, K. A., and Nielsen, A. L. (2013). Tracing the origin of US brown marmorated stink bugs, Halyomorpha halys. Biol. Invasions 16, 153-166. doi: 10.1007/s10530-013-0510-3

Yu, D. J., Zhang, G. M., Chen, Z. L., Zhang, R. J., and Yin, W. Y. (2004). Rapid identification of Bactrocera latifrons (Diptera, Tephritidae) by realtime PCR using SYBR Green chemistry. J. Appl. Entomol. 128, 670-676. doi: 10.1111/j.1439-0418.2004.00907.x

Yu, G., and Zhang, J. (2007). "The brown marmorated stink bug, Halyomorpha halys (Heteroptera: Pentatomidae) in PR China," in International Workshop on Biological Control of Invasive Species of Forests, eds Y. Wu and X. Y. Wang (Beijing: USDA Forest Service), 70-75.

Zhu, G., Bu, W., Gao, Y., and Liu, G. (2012). Potential geographic distribution of brown marmorated stink bug invasion (Halyomorpha halys). PLoS ONE 7:e31246. doi: 10.1371/journal.pone.0031246

Conflict of Interest Statement: The authors declare that the research was conducted in the absence of any commercial or financial relationships that could be construed as a potential conflict of interest.

Copyright $\odot 2016$ Dhami, Dsouza, Waite, Anderson and Li. This is an open-access article distributed under the terms of the Creative Commons Attribution License (CC $B Y)$. The use, distribution or reproduction in other forums is permitted, provided the original author(s) or licensor are credited and that the original publication in this journal is cited, in accordance with accepted academic practice. No use, distribution or reproduction is permitted which does not comply with these terms. 